\title{
Peranan Media Sosial dan Teknologi Informasi Dalam Memajukan Pembangunan Daerah
}

\author{
${ }^{1}$ Havid Syafwan, ${ }^{2}$ Pristiyanilicia Putri, ${ }^{3}$ Masitah Handayani \\ ${ }^{1}$ Prodi Manajemen Informatika, STMIK ROYAL Kisaran, Sumatera Utara \\ ${ }^{2,3}$ Prodi Sistem informasi, STMIK ROYAL Kisaran, Sumatera Utara
}

e-mail: havid_syafwan@yahoo.com

\begin{abstract}
Abstrak - Penggunaan media sosial saat ini sangatlah besar dan berdampak kepada kehidupan sosial masyarakat luas selaras dengan berkembangnya Teknolog Informasi. Dengan adanya media sosial tentunya dapat mengurangi keterbatasan manusia dalam berinteraksi dan berkomunikasi antara satu dengan yang lainnya. Salah satu hal positif dari penggunaan media sosial ini adalah dalam menyampaikan informasi dengan cepat kepada masyarakat luas khususnya dalam memajukan pembangunan di daerah. Adapun kegiatan pengabdian ini dilaksanakan dalam bentuk sosialisasi atau menyampaian materi singkat yang dilanjutkan dengan diskusi dimana kegiatan ini bertujuan untuk memberikan wawasan mengenai penggunaan media sosial yang baik dan benar sehingga mampu memberikan manfaat bagi para penggunanya. Peserta pada kegiatan ini adalah para anggota masyarakat yang tergabung dalam Lembaga Peran Pembangunan Asahan (LEPPAS). Hasil dari kegiatan pengabdian ini adalah berupa pemahaman materi bagi para peserta kegiatan yang nantinya dapat mengimplementasikan peran media sosial dalam memajukan pembangunan daerah khususnya di Kabupaten Asahan.
\end{abstract}

Kata kunci - Media Sosial, Pembangunan, Teknologi Informasi, LEPPAS Asahan

\begin{abstract}
The use of social media today is very large and has an impact on the social life of the wider community in line with the development of Information Technology. The existence of social media can certainly reduce human limitations in interacting and communicating with each other. One of the positive things about the use of social media is in conveying information quickly to the wider community, especially in advancing development in the region. The devotional activities are carried out in the form of socialization or delivering short materials followed by discussions where this activity aims to provide insights on the use of social media that is good and correct to provide benefits for its users. Participants in this activity are members of the community who are members of the Asahan Development Role Institute (LEPPAS). The result of this devotion activity is in the form of material understanding for the participants of activities that will be able to implement the role of social media in advancing regional development, especially in Asahan Regency.
\end{abstract}

Keywords - Social Media, Development, Information Technology, LEPPAS Asahan

\section{PENDAHULUAN}

Penggunaan media sosial saat ini seakan-akan menjadi sebuah kebutuhan pokok yang keberadaannya sangat dibutuhkan banyak orang. Sebagai contoh, jika beberapa menit saja seseorang tidak melihat gadget mereka, maka seakan-akan ada sesuatu yang kurang. Dapat di analogi jika seseorang makan tiga kali dalam sehari dalam waktu yang cukup lama, maka masih bisa untuk bertahan hidup, tapi ketika seseorang sebentar saja tidak melihat gadget dan mengecek media sosial, maka ada sebuah kondisi yang membuat tubuh mereka akan mengalami hal yang tidak biasa, yang biasa di kenal dengan istilah "kecanduan" media sosial [4].

Penggunaan media sosial memberikan pengaruh yang nyata pada keberlangsungan hidup manusia saat ini. Seseorang yang "kecil" di mata masyarakat akan dianggap "besar" melalui adanya sosial media, begitu juga kebalikannya dimana jika seseorang dianggap "besar" bisa saja dalam waktu singkat menjadi "kecil" akibat dari kesalahannya dalam menggunakan media sosial [1].

Banyak manfaat yang bisa dirasakan dari penggunaan media sosial antara lain dalam berdagang, memasarkan produk, mencari relasi, pertemanan, dan lain-lain. Namun bahayanya jika tidak bisa mengendalikan media sosial dengan baik, maka seseorang akan terjerumus dalam bahayanya media sosial tersebut apakah itu langsung ataupun tidak langsung seperti kecanduan gadget, individualistis, suka berkhayal, dan lain-lain [4].

Orang yang memiliki pola pikir yang cerdas akan menggunakan media sosial untuk mempermudah mereka untuk setiap aktifitas seperti mencari pekerjaan, belajar, jual beli, mencari informasi dan lain-lain [6].

Melihat kenyataan tersebut, maka perlu adanya sebuah metode yang dipakai untuk memanfaatkan media sosial dengan baik dan bijak, baik itu dari segi 
durasi, waktu, tujuan penggunaannya, cara menggunakannya, larangan dalam bermedia sosial serta bagian-bagian lainnya [2].

Lembaga Peran Pembangunan Asahan (LEPPAS) yang merupakan salah satu lembaga yang ada di Kab. Asahan yang mengayomi para anggotanya untuk memberikan kontribusinya guna untuk kemajuan pembangunan fisik dan non fisik di kab, Asahan. Pembangunan fisik meliputi sarana dan prasarana seperti jalan, pasar, jembatan, pertanian dan irigasi. Sedangkan pembangunan non fisik meliputi pembangunan manusia, pendidikan, kesehatan, dan ekonomi [5].

Sebagai anggota LEPPAS yang mayoritas terdiri dari generasi muda, tentu perlu kiranya untuk mendapatkan tambahan wawasan mengenai perkembangan ilmu pengetahuan terutama dalam bidang Teknologi informasi berkaitan dengan peran media sosial dalam memajukan pembangunan di daerahnya.

Berdasarkan dari penjelasan tersebut, maka Lembaga LEPPAS bekerja sama dengan dosen-dosen STMIK Royal Kisaran dalam bentuk kegiatan Pengabdian Kepada masyarakat (PKM) kepada para anggota LEPPAS yang bertujuan untuk memberikan informasi dan wawasan pengetahuan dengan harapan nantinya dapat diimplementasikan mengenai manfaat media sosial dalam memajukan pembangunan daerah di Kabupaten Asahan.

\section{METODE PELAKSANAAN}

Pelaksanaan kegiatan ini dilakukan dalam bentuk sosialisasi atau menyampaian materi singkat yang meliputi beberapa tahapan pelaksanaan kegiatan, sebagai berikut [2]:

1. Persiapan..

a. Menghubungi dan menelusuri pihak lembaga LEPPAS dalam merencanakan kegiatan Pengabdian dan langkah-langkah yang akan dilaksanakan terhadap kegiatan tersebut. Kemudian mencari jadwal awal pertemuan untuk mendiskusikan kegiatan tersebut.

b. Observasi...dalam bentuk survei lokasi awal, mengadakan pertemuan langsung dengan pihak pimpinan dan menelusuri seberapa penting materi yang akan disampaikan berkaitan dengan peran media sosial dalam pembangunan daerah di Kabupaten Asahan.

c. Mencari berbagai macam referensi yang relevan dan data-data pendukung lainnya untuk menyampaikan materi.

\section{Sosialisasi}

Kegiatan pengabdian ini dilaksanakan berkelompok melalui tatap muka langsung dengan para peserta, menyampaikan materi, kemudian dilanjutkan dengan diskusi. Beberapa materi yang dijelaskan pada bagian sosialisasi ini, antara lain : a. Selayang pandang tentang kampus STMIK Royal, perkenalan tim dosen pengabdian, dan pemahaman dasar mengenai media sosial.

b. Definisi dari media..sosial

c. Perkembangan..dari media..sosial

d. Manfaan dan bahaya media sosial

e. Korelasi media...sosial dengan kemajuan pembangunan daerah

3. Contoh kasus keterkaitan media sosial dengan kemajuan pembangunan daerah dalam bidang infrastruktur

4. Tahap..evaluasi

Tahapan ini dilakukan.. setelah.....proses penyampaian materi melalui diskusi dan tanya jawab dengan para peserta untuk mengukur tingkat pemahaman dari kegiatan tersebut.

\section{HASIL DAN PEMBAHASAN \\ Pengantar Media Sosial}

Media sosial atau juga dikenal dengan sosial media adalah suatu media yang digunakan untu berinteraksi dan bersosialisasi antara seseorang dengan orang lain yang dilakukan secara online sehingga orang tersebut bisa saling berinteraksi dan berkomunikasi secara luas [4].

Dengan adanya media sosial dapat mengurangi batasan-batasan seseorang dalam bersosialisasi serta mampu menghapus jarak dan waktu. Melalui media sosial seseorang bisa saja untuk saling berinteraksi antara satu dengan yang lain dimanapun dan kapanpun mereka berada.

Media sosial dapat dibagi dalam beberapa kelompok yaitu [4] :

1. Social...Networks, digunakan dalam berinteraksi dan bersosialisasi (seperti : Facebook, Whatsapp, Twiter, Istagram, dll )

2. Forum...Discuss, digunakan untuk membantu sekelompok orang dalam obrolan dan diskusi (seperti : yahoo!, google talk, Skype, phorum)

3. Share.., digunakan untuk berbagi file, video, music (seperti : youtube, slideshare, feedback, flickr)

4. Publish.., digunakan dalam mempublikasikan informasi (seperti : wordpredss, wikipedia, blog, wikia, digg)

5. Social...game, merupakan game permainan yang bisa digunakan atau dimainkan secara bersamasama (seperti : koongregate, doof, pogo, cafe.com)

6. MMO... (kartrider, warcraft, neopets, conan)

7. Livecast... (yahoo! Live, blog..tv, justin tv, listream..tv, livecastr)

8. Livestream... (socializr, froendsfreed, socialthings)

9. Micro...blog (twitter, plurk, pownce, twirxr, plazes, tweetpeek)

Sumber We are Social, Hootsuite tahun 2020 diperoleh informasi berupa 10 media sosial yang sangat sering dimanfaatkan di negara Indonesia, 
Adapun platform yang paling sering digunakan di Indonesia adalah Youtube yang berumur 16 sampai 64 tahun. Ada sekitar $88 \%$ pengguna yang mengakses Youtube. Selanjutnya diikuti oleh WhatsApp sebesar $84 \%$, Facebook sebesar 82\%, dan Instagram 79\% [6].

Rata-rata waktu yang digunakan masyarakat Indonesia dalam menggunakan sosial media adalah sekitar 3 jam 26 menit. Jumlah pemakai aktif dari media sosial sebesar 160 juta atau 59\% dari jumlah penduduk Indonesia dimana $99 \%$ pemakai media sosial menggunakan ponsel atau Handphone sebagai alat dalam mengakses media sosial tersebut [6].

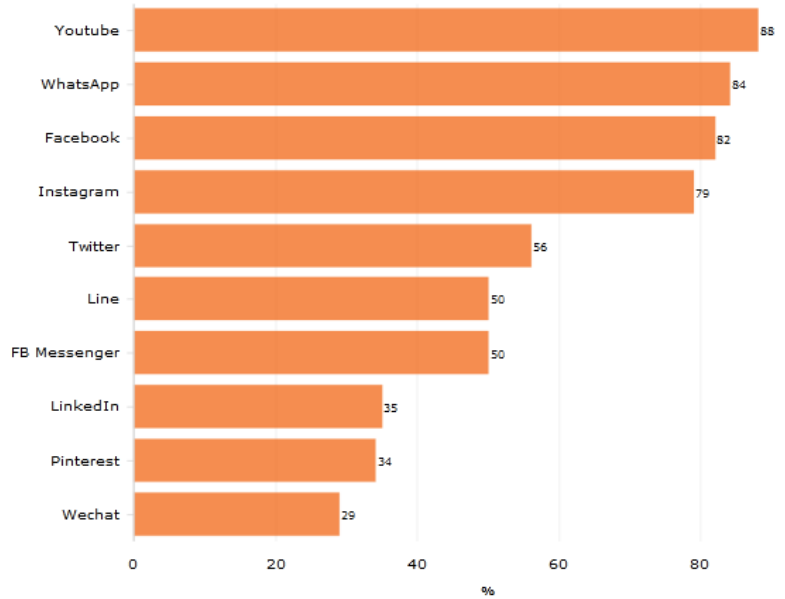

Gambar 1. 10 Media sosial yang paling sering digunakan di Indonesia

\section{Peran Media Sosial dalam Pembangunan}

Bersamaan dengan perkembangan jumlah penduduk serta bertambahnya tingkatan mobilitas warga, hingga hampir berakibat pada terus luasnya koneksi infrastruktur yang diperlukan oleh masyarakat. Tetapi pada kondisi lain kepiawaian pemerintah dalam penyelenggarakannya sangat terbatas. Dengan demikian perlu rasanya membangun suatu pola kerjasama yang tentunya dapat saling menguntungkan antara pemerintah dengan warga. Warga mestinya sadar akan keberlangsungan suatu infrastruktur hingga perannya sangat diharapkan dan tidak berubah-ubah. Tiap tahun arah mobilisasi masyarakat terus bergerak sehingga wajib diperkuat kerjasama antara pemerintah dan masyarakat tersebut.

Jalan merupakan satu diantara infrastruktur yang begitu berpengaruh dalam kehidupan masyarakat dalam proses perkembangan daerah, kondisi ini sebaiknya menjadi perhatian pemerintah dalam memajukan serta menaikkan keinginan masyarakat dalam memajukan pembangunan infrastruktur. Didalam masa transparasi dan keterbukaan informasi saat ini, meningkatkan rasa kesadaran masyarakat tentang perlunya menjaga dan memelihara infrastruktur yang tentunya bisa memudahkan pihak pemerintah untuk menjalankan rencana-rencana yang sudah dipersiapkan, melalui sikap saling percaya dan kebersamaan antara pemerinta dengan masyarakatnya.

Di era keterbukaan informasi publik yang saat ini tidak bisa kita pungkiri keberadaan dan perkembangannya, maka tentunya dibutuhkan kesiapan dan tanggungjawab dari sebuah sistem informasi yang pastinya berguna untuk kemajuan dalam berbagai bidang yang menjadi tujuan dari sebuah lembaga pemerintahan. Perkembangan Media sosial yang semakin luas mesti disikapi secara positif dalam memajukan keikutsertaan masyarakat untuk menciptakan prinsip tata kelola lembaga pemerintahan yang baik dan benar. Pada situasi tersebut lembaga Humas pemerintahan sangat diharapkan perannya sebagai bagian dari pengelola informasi terutama dalam memanfaatkan perkembangan media sosia yang tentunya akan sangat strategis dan diperlukan terutama dalam menyebarluaskan informasi kepada pihak masyarakat.

Didalam Undang-undang No. 14 Tahun 2008 yang berisikan tentang Keterbukaan Informasi Publik, dapat dijelaskan mengenai hak seseorang dalam mendapatkan informasi adalah hak asasi dari setiap orang dan keterbukaan mengenai informasi yang menjadi suatu ciri-ciri penting dari sebuah negara demokrasi dalam mengutamakan kedaulatan bangsa. Transparansi akan informasi publik menjadi suatu wadah untuk memaksimalkan fungsi pengawasan publik serta menjadi bagian dari cara dalam memajukan informasi yang berkualitas bagi masyarakat. Kemudian, pada Pasal 2 Undang-Undang No. 14 Tahun 2008 dijelaskan bahwa semua informasi publik wajib diperoleh dan didapatkan dengan cepat, biaya yang murah, serta dengan cara yang mudah [3].

Dengan memanfaatkan teknologi informasi, terutama dengan adanya media sosial atau jejaring sosial untuk menjalankan keterbukaan informasi publik menjadikan suatu inovasi yang sangat penting dimana memiliki sifat yang mudah diakses, tepat waktu serta mudah dan murah.

Dinas Pekerjaan Umum (PU) sebagai penanggungjawab dalam pembangunan di bidang infrastruktur mempunyai kewajiban dalam mendukung setiap sektor guna keberlanjutan hidup dan kehidupan masyarakat, diantaranya adalah dalam sektor pangan, perekonomian, dan kualitas masyarakat. Dikarenakan begitu pentingnya kegiatan pembangunan infrastruktur sehingga diharuskan memiliki infrastruktur yang mempunyai hasil dan kualitas yang baik serta dapat menyelesaikan masalah yang sifatnya nonteknis pada sektor ekonomi, lingkungan, serta kehidupan bersosial sehingga dibutuhkan suatu media yang mudah diakses serta dapat menjangkau setiap lapisan masyarakat baik itu dalam hal mendapatkan informasi ataupun dalam pelaporannya [5].

Secara tidak langsung, media sosial sebagai bagian dari teknologi informasi yang sangat populer digunakan dari berbagai lapisan masyarakat tentunya 
Jati Emas (Jurnal Aplikasi Teknik dan Pengabdian Masyarakat)

Vol. 5 No. 1 Maret 2021 - e. ISSN: 2550-0821

akan memberikan kemudahan dalam mengatasi berbagai macam kendala nonteknis di atas. Melalui Puslitbang Sosekling (Sosial, ekonomi, dan lingkungan) dari Badan Litbang PU akan terus berinovasi guna mendukung kegiatan-kegiatan litbang serta pengembangan infrastruktur yang tentunya akan mempertimbangkan aspek kehidupan sosial, perekonomian, dan keadaan lingkungan. Pada kesimpulannya, tentunya dalam pelaksanaan pembangunan infrastruktur dapat memberikan dampak yang positif bagi warga dan tentunya bagi lingkungan [5].

Dari kegiatan pengabdian kepada masyarakat ini dengan tema peranan media sosial dan teknologi informasi dalam memajukan pembangunan daerah telah didokumentasi beberapa aktifitas yang ditunjukkan dalam bentuk gambar berikut ini :

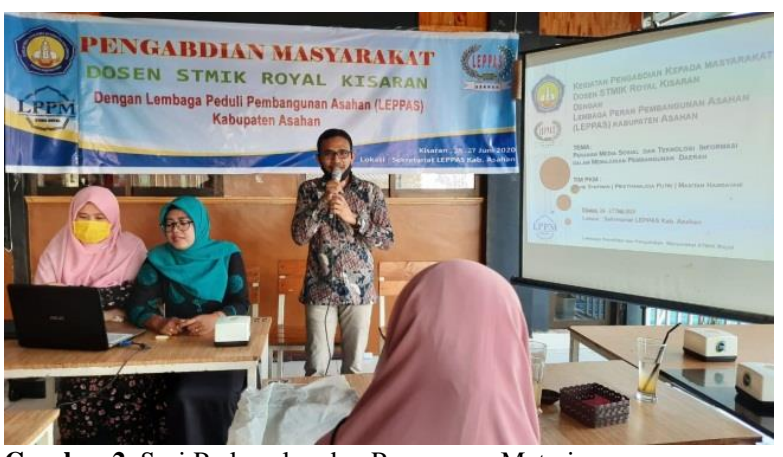

Gambar 2. Sesi Perkenalan dan Pemaparan Materi

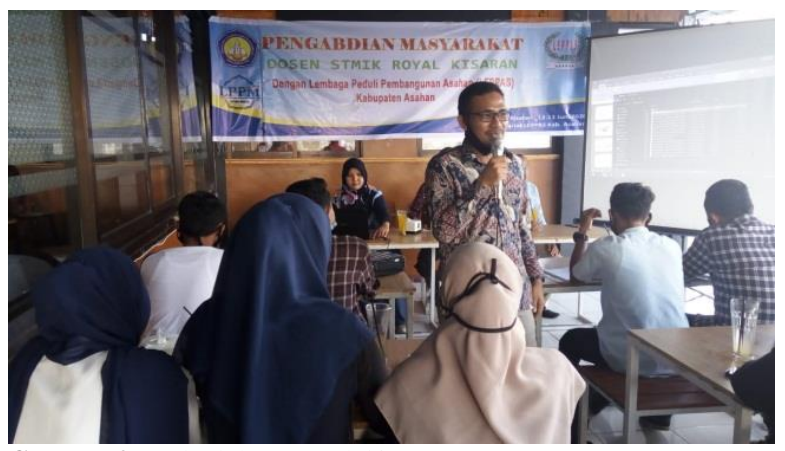

Gambar 3. Sesi Dialog Interaktif

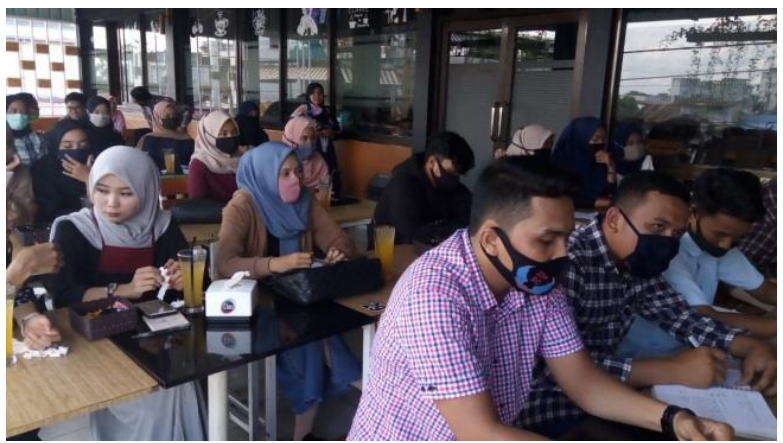

Gambar 4. Para Peserta Kegiatan PKM

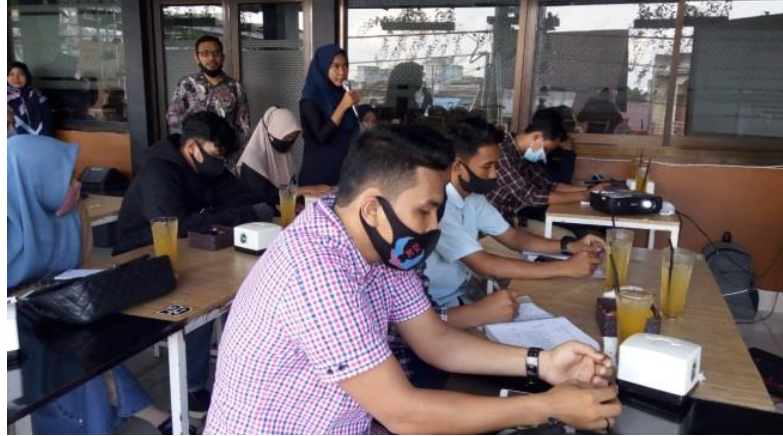

Gambar 5. Sesi Diskusi dan Tanya Jawab

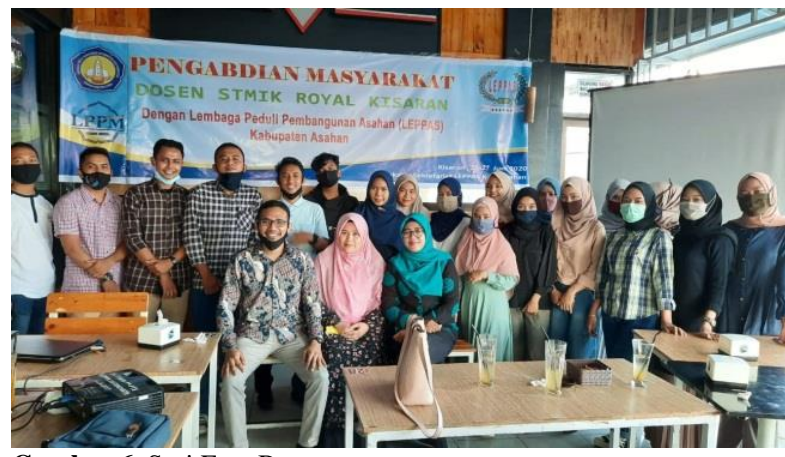

Gambar 6. Sesi Foto Bersama

\section{KESIMPULAN}

Adapun kesimpulan dari pelaksanaan kegiatan pengabdian masyarakat ini adalah kegiatan ini dilakukan dalam bentuk sosialisasi dimana tujuannya memberikan tambahan wawasan mengenai peran dan penggunaan media sosial yang baik dan benar sehingga mampu memberikan manfaat bagi para penggunanya, sehingga nantinya dapat diimplementasikan bagi para peserta kegiatan dalam menyampaikan informasi-informasi yang sifatnya dapat memajukan pembangunan daerah khususnya di Kabupaten Asahan.

Adapun saran untuk kegiatan selanjutnya adalah agar kiranya kegiatan-kegiatan pengabdian seperti ini dapat dijalankan secara berkala dan berkesinambungan antara lembaga LEPPAS dengan kampus STMIK Royal Kisaran.

\section{DAFTAR PUSTAKA}

[1] Fadhli, M., \& Fadlilah, M. (2017). Pelatihan Pemanfaatan Media Sosial dan Blog Sebagai Sarana Publikasi Bustanul Athfal Kabupaten Ponorogo. Adimas: Jurnal Pengabdian Kepada Masyarakat, 1(2), 18-24

[2] Rahmawan, D. (2018). Pelatihan Literasi Media Sosial Terkait Penanggulangan Hoaks Bagi Siswa SMA. Jurnal Pengabdian Kepada Masyarakat, 2(12), 1021-1024. 
Jati Emas (Jurnal Aplikasi Teknik dan Pengabdian Masyarakat)

Vol. 5 No. 1 Maret 2021 - e. ISSN: 2550-0821

[3] Undang-Undang Nomor 14 Tahun 2008 Tentang Keterbukaan Informasi Publik.

[4] http://www.unpas.ac.id/apa-itu-sosial-media/
[5] https://www.elisakaramoy.com/2013/11/peranmedia-sosial-dalam-pembangunan.html

[6] https://datareportal.com/reports/digital-2020indonesia 
